\title{
РЕЛІГІЄЗНАВСТВО
}

УДК 2-67-78(477)

DOI 10.35423/2078-8142.2021.2.1.10

Ю. Ю. Корнійчук,

кандидат філософських наук, докторантка кафедри богослов'я та релігієзнавства Національного педагогічного університету імені М. П. Драгоманова, м. Київ, Украӥна e-mail: iu.korniichuk@npu.edu.ua ORCID: https://orcid.org/0000-0003-3346-4920

\section{МІЖРЕЛІГІЙНІ ОРГАНІЗАЦІЇ: СТАН І НАПРЯМИ ДОСЛІДЖЕНЬ В УКРАЇНСЬКОМУ КОНТЕКСТІ}

На відміну від міжрелігійного діалогу, щзо став предметом ретельних розвідок як українських, так і світових дослідників релігіï, увага до міжрелігійних організацій лишається непропориійно меншою від їх ролі у суспільному житті та на міжнародній арені. Стаття присвячена системному огляду головних напрямів сучасних досліджень міжрелігійних організаиій. Послідовно розкриваються чотири аспекти: 1) можливі причини недостатньої дослідницької уваги до міжрелігійних організацій (зокрема вплив теорії секуляризаиії та порівняна «молодість» більшості з них); 2) проблема означення змісту поняття «міжрелігійні організаиії» (розширення кола дієвиів, які можуть виступати від імені релігійних організаиій, порівняння підходів до розуміння міжрелігійних організаиій з висунутими ООН критеріями означення міжнародних організацій); 3) сучасні підходи до класифікації міжрелігійних організацій за колом учасників та складності адаптації изих класифікацій до українського контексту - неперекладності, зміни акценттів, начіональні преференції та усталеності; 4) функції міжрелігійних організачій на міжнародній арені та пов'язані з ними виклики: загроза політичної інструменталізації, проблема репрезентативності та включеності всіх дієвців, щуо особливо актуально для українських релігійних організацій, які в своїй більшості не

(C) Корнійчук Ю. Ю., 2021 
мають самостійного представництва в міжнародних міжрелігійних організаціях. У висновках окреслено перспективи подальшого вивчення теми в контексті входження украӥнських релігійних організацій у міжнародне релігійне поле.

Ключові слова: міжрелігійні організації, міжконфесійні організації, релігія в публічній сфері, організащї, створені на підставі віри, Парламент релігій світу, Всесвітня Рада Церков.

ХХ століття ввійшло в історію не лише як епоха двох світових воєн, а і як час гострого усвідомлення кончої потреби широкого суспільного діалогу - політичного, соціального, релігійного. Менш ніж за століття ідея діалогу між релігіями минула шлях від сміливих мрій та експериментів окремих ентузіастів до широкого організаційно оформленого руху.

Сьогодні міжнародні та національні міжрелігійні організації $\epsilon$ активними суспільними дієвцями. Вони відіграють важливу роль не лише у сферах, які історично вважалися предметом зацікавлення релігійних організацій, а саме - соціальній та гуманітарній допомозі, освіті, а й у розбудові локальних громад, миротворчості, сприянні сталому розвитку тощо. Структури, завданням яких $є$ налагодження співпраці з релігійними/міжрелігійними організаціями, мають практично всі ключові міжнародні організації - від ООН та ЄC до Світового банку чи Давоського економічного форуму. Попри це, дослідницька увага до міжрелігійних організацій є непропорційно меншою від їх присутності в публічній сфері.

Серед причин такого дослідницького «недогляду» варто насамперед згадати низку упереджень щодо релігії як такої. Попри активне зацікавлення організаційною стороною релігії класиків соціології релігії (Дюркгейма, Вебера, Трьольча та ін.), теорія секуляризації, яка домінувала протягом майже всієї другої половини XX ст., перетворила релігію не лише на «приватну справу» чи «неактуальну тему», а й змусила представників багатьох суспільних наук сумніватися в самій «прийнятності» релігії як об'єкта наукового дослідження [18, с. 5-8].

Додає труднощів і порівняна «молодість» більшості міжрелігійних організацій. Парламент релігій світу, який часто називають історично першою міжрелігійною організацією, тривалий час мав 
радше символічне, ніж практичне значення, адже між першим та другим його зібраннями минуло ціле століття (відповідно, 1893 і 1993 роки). Навіть такі потужні післявоєнні міжрелігійні ініціативи, як-то Всесвітня Рада Церков (створена 1948) чи Конференція Європейських Церков (1959), так і не стали масовими. Їх діяльність відома переважно в когорті церковних ієрархів та профільних дослідників. А більшість міжрелігійних організацій з'явилася вже в 1990-ті [8, с. 303] - на початку 2000-х років [4, с. 42; 5, с. 1]. У першому разі каталізатором появи нових міжрелігійних організацій стало проведення другого зібрання Парламенту релігій світу, у другому - потреба напрацювання нових умов співжиття християн та мусульман після терористичних атак 11 вересня 2001 р. Окремі дослідники часом визначають хвилю 2000 -х років як умовно «мусульманську» через стрімке зростання кількості міжрелігійних організацій, що включають або постали за ініціативи мусульман (наприклад, див.: [5]). Таким чином, стрімке зростання кількості та ваги міжрелігійних організацій у публічній сфері $є$ порівняно недавнім феноменом, що зумовлює певну фрагментарність їх досліджень.

У цьому контексті важливо розділяти розвідки, присвячені міжрелігійному діалогу та власне міжрелігійним організаціям. Якщо перший став об'єктом детального аналізу як в Україні, так і за кордоном, дослідження останніх є радше поодинокими винятками.

Серед прикладів аналізу функціонування власне міжрелігійних організацій є нещодавні серії статей у журналах «Соціальний компас» («Social Compass» 2018, 65/3) і «Огляд релігії та міжнародних відносин» («The Review of Faith \& International Affairs», 2018, 16/3). На прикладі низки країн (Великобританія, Данія, Іспанія, Італія, Німеччина, Норвегія, Швеція, США, Катар, Йорданія та ін.) автори цих досліджень демонструють широкий спектр можливих аспектів дослідження діяльності національних міжрелігійних організацій: від особливостей їх формування, фінансування та взаємодії з локальною/центральною владою і громадянським суспільством, до ролі в «управлінні релігійним багатоманіттям» (англ. governance of religious diversity) [8; 14; 16], підвищенні рівня толерантності чи ненасильницької взаємодії в суспільстві, м’якої сили 
на міжнародні арені тощо. Поряд з цим, згадані розвідки є радше запрошенням до ширшого дослідження системи національних та міжнародних міжрелігійних інституцій, яку в згаданих дослідженнях уже визначають як окремий «міжрелігійний сектор» [17, с. 367-368].

Актуальним дослідження міжрелігійних організацій $є$ i в українському контексті. Йдеться не лише про активну соціальну позицію українських міжрелігійних організацій, зокрема Всеукраїнської Ради Церков і релігійних організацій всередині країни, а й про міжнародний вимір їх діяльності. Після окупації Криму та російської збройної агресії у Східній Україні міжрелігійні організації стали одним з авторитетних голосів на міжнародній арені, що здатен протистояти російській дезінформації та привертати увагу до порушення прав людини на тимчасово окупованих територіях. Глибше дослідження системи міжрелігійних організацій може бути корисним і для кращого усвідомлення релігійними організаціями власного потенціалу, і для ефективної відповіді на ті виклики, що сьогодні стоять перед релігійними організаціями та суспільством загалом.

Метою цієї статті є загальний огляд системи міжрелігійних організацій, іiі рівнів, форм, функцій та особливостей дослідження діяльності міжрелігійних організацій в українському контексті.

Що таке міжрелігійні організаціï? Термін «міжрелігійна організація» $є$ і простим, і складним водночас. 3 одного боку, він здається самозрозумілим - організація, створена «між релігіями», тобто двома чи більше сторонами, які представляють різні релігійні традиції. Однак, на якому рівні має бути таке представництво? Чи обов'язково має йтися про формальні релігійні структури? Яких форм можуть набувати релігійні, а отже, і міжрелігійні організації сьогодні? Відповіді на всі ці питання з часом стають дедалі складнішими та розлогішими.

Від самого початку розвитку екуменічного руху, його творців об'єднувало прагнення до єдності, але не спільна візія шляхів іiі досягнення. Яскравим прикладом тут $є$ передісторія найбільшої 3 міжхристиянських організацій - Всесвітньої Ради Церков (далі ВРЦ). До злиття в єдину формалізовану структуру (що відбулося у 1948), вона кілька десятиліть існувала як низка різноспрямованих 
ініціатив: богословської, соціальної та місіонерської, що загалом відображає основний спектр підходів до бачення єдності. Така різноликість збереглася і в сучасній структурі організації. 3 одного боку, вона дає можливість (через соціальну складову) залучити до руху ширше коло учасників, не обмежуючи його виключно релігійними ієрархами, а з іншого (через богословську) - означити його межі та спрямування.

3 1980-х, на хвилі частково кризи богословського діалогу, частково «повернення» релігії, розвиток соціально спрямованих міжрелігійних ініціатив набуває нової сили та дихання. Безпосереднім результатом цього стало виокремлення нового типу організацій - організаиій, створених на підставі віри (англ. faith-based organizations, FBOs). Поєднуючи в собі характеристики релігійної організації та недержавних/неурядових організацій (НДО/НУО), вони швидко завоювали увагу та визнання як урядів низки країн (наприклад, США, Німеччини), так і міжнародної спільноти - приблизно кожна десята НДО, акредитована при Економічній та соціальній раді $\mathrm{OOH}, \epsilon$ організацією, створеною на підставі віри [9, с. 2]. Як доводить Джівонс, таке «опертя на віру» може набувати різних форм - від самоідентифікації та приналежності членів організації до принципів ії діяльності, декларованих ідеалів, продукува́них послуг чи джерел фінансування [10, с. 79-95].

На відміну від соціальних відділів міжрелігійних/міжконфесійних організацій-важковаговиків (як, наприклад, вже згадана ВРЦ), організації, створені на підставі віри, є вільнішими у своїй діяльності, не мають низки конотацій, пов'язаних 3 релігійними організаціями (наприклад, орієнтованість на місіонерство/навернення), хоча й часто розглядаються реципієнтами як «менш професійні», порівняно з нерелігійними [12, с. 55].

Розглядаючи спектр суб'єктів, що можуть сьогодні виступати «від імені» тієї чи іншої релігії (формальна інституція, організації на підставі віри, окремі віряни), Грієра та Нагель виокремлюють два режими членства та представництва: 1) товариський (англ. fellowship), що передбачає можливість представництва на рівні окремих вірян чи невповноважених до представництва всієї традиції асоціацій та 2) представницькі інституції (англ. representative 
$b o d y)$, що мають своєрідний мандат виступати від імені всієї спільноти [8, с. 305-306].

Загалом, згадані автори висувають три критерії, яким має відповідати ініціатива аби називатися міжрелігійною організацією: 1) об'єднувати представників/вірян щонайменше двох релігійних традицій, 2) мати певну структуру і тяглість, 3) керуватися бажанням працювати з представниками різних релігій заради розбудови спільноти та розвитку взаєморозуміння [8, с. 305].

Певною мірою ці критерії відлунюють прийняті в ООН критерії до визначення міжнародних організацій [19]. Спільним для обох класифікацій є наявність мінімальної організаційної структури та планування діяльності, що відрізнятиме починання від окремих ситуативних акцій (у випадку вимог до нерелігійних міжнародних організацій - наявність секретаріату). Частковий збіг і вимога щодо кола учасників, однак, якщо згадані автори означують як мінімальний поріг дві сторони, то загальноприйнятим у разі нерелігійних є все ж три. Організації, створені за представництва двох сторін, означуються як білатеральні/двосторонні. Поряд з цим, варто наголосити, що питання мінімальної кількості сторін у випадку міжрелігійних організацій є радше відкритим, а двосторонні міжрелігійні ініціативи досить часто також позначаються як «білатеральні міжрелігійні» (наприклад, див.: [15, с. 351]). Останнім, третім критерієм ООН для міжнародних організацій $є$ наявність формального договору між сторонами, що у разі релігійної сфери може позначатися менш формально та юридично зобов'язальними «бажанням» чи «орієнтацією» на співпрацю.

Така «спільна мета» часто-густо стає причиною не завжди коректного ототожнення міжрелігійних організацій з екуменічними. Попри різнобій підходів до розуміння самого екуменічного руху та його мети, на порядку денному міжрелігійних організацій питання релігійної єдності зовсім не обов'язкове. Досить часто міжрелігійні організації є радше «спільнотами долі» (англ. community of fate (Ханна Арендт)) - організаціями, що постали 3 представників різних традиції, що проживають на спільній території, а отже, зіткнулися з одними тими самими проблемами і викликами.

Вибір імені - вибір долі: проблема понятійного означення $i$ класифікаціï. В англомовній літературі існує широкий спектр тер- 
мінів, що використовуються як синонімічні до терміна «міжрелігійна організація». Попри те, що на практиці надання переваги тому чи іншому терміну часто зумовлене національною специфікою, вони все ж відображають розглянуту вище різноманітність можливих сторін-членів організації. Найбільш часто згадуваними в українських дослідженнях є терміни міжрелігійні (англ. inter-religious) та міжконфесійні (англ. inter-confessional) організації. Перший 3 термінів використовується щодо організацій, що об'єднують різні релігійні традиції, другий - різні конфесії (гілки, течії) в межах тієї самої релігії. Класичним прикладом міжрелігійної організації може бути вже згаданий Парламент релігій світу (об'єднує християн, мусульман, буддистів, індуїстів та н.), міжконфесійної - ВРЦ, яка об'єднує представників різних християнських конфесій (православних, орієнтальних, протестантів, частково католиків). Принагідно зауважимо, що Католицька церква використовує гнучкий підхід до представництва у ВРЦ: вона є членом окремих комісій (зокрема 3 богословського діалогу), до інших - делегує лише спостерігачів.

Водночас, в англомовних розвідках термін inter-religious (укр. міжрелігійний) дедалі частіше поступається на користь більш інклюзивному inter-faith, що наразі не має усталеного українського перекладу. Показовими є переклади англійського терміна faithbased diplomacy, який залежно від автора чи перекладача українською можна побачити у версіях релігійна дипломатія; дипломатія на підставі віри; дипломатія на засадах/принципах віри; дипломатія, заснована на релігійних переконаннях. У польському варіанті термін набуває ще одного відтінку - dyplomacja oparta o wiare (укр. дипломатія, що опирається на віру). Загалом, термін faith (укр. віра) хоч і може використовуватися як синонім релігії, все ж переносить акцент з організації та ієрархії на переконання та світогляд, стаючи більш доречним коли йдеться про представництво не тільки на рівні репрезентативних інституцій, а й організацій на підставі віри чи вірян. Певною мірою, англійське inter-faith organizations можна перекласти українською як міжвіросповідні організаuฺï, хоча такий переклад має свої недоліки. Попри те, що словникове значення слова «віросповідання» $є$ релігійно-нейтральним, воно все-таки часто асоціюється насамперед з християнством. 
Інший «проблемний» термін - inter-convictional organizations (англ. conviction - укр. переконання), що ще більше розширює коло представників/учасників, допускаючи до нього також нерелігійних дієвців. До прикладу, Європейська мережа з релігії та переконань (The European Network on Religion and Belief, ENORB) визначає ceбе як організацію, що об'єднує «міжвіросповідні та засновані на переконаннях організації, церкви, релігійні, філософські та неконфесійні асоціації» [10]. Таке зрівняння релігійних та нерелігійних асоціацій не лише відповідає офіційній політиці $Є \mathrm{C}$, а й відображає релігійну специфіку окремих країн. Наприклад, перевага терміна «організації, засновані на переконаннях» порівняно 3 міжрелігійними організаціями на національному рівні відчутна у Франції.

Зрештою, дискусивним є i сам префікс між-[релігійний/віросповідний тощо]. Як зауважує Канін, цей префікс має радше уніфікаційну конотацію та опирається на певному спільному мінімумі, що непрямо відкидає багатоманіття як цінність. Із цієї причини низка насамперед нерелігійних організацій, що надають майданчики для міжрелігійної співпраці (наприклад, ООН), дедалі частіше надають перевагу терміну multi-faith (мульти-/багатовіросповідна організація) [11].

Таким чином, наведений спектр термінів може слугувати як одна зі спроб класифікувати міжрелігійні організації за колом їх учасників - від найвужчого - міжконфесійного, до найширшого заснованого на певних переконаннях. Водночас, зростання різноманіття учасників не завжди означає пропорційного ускладнення співпраці чи роботи організації і навпаки (звуження - спрощення).

Крім того, сучасні міжрелігійні організації можна класифікувати за низкою інших критеріїв: територією діяльності (локальні/національні/міжнародні (регіональні чи глобальні), напрямами роботи (миротворчі/соціальні/освітні/правозахисні/орієнтовані на адвокацію/лобіювання та ін.) тощо. Цікавим «серединним» явищем, що не потрапляє до цієї класифікації, є транснаціональні релігійні організації. Попри свою релігійну одноманітність їх внутрішнє культурне різноманіття та різнобій часто-густо взаємосуперечливих проблем, що стоять перед ними, може не поступатися міжрелігійним організаціям. Яскравим прикладом тут є Католиць- 
ка церква, яку часто напівжартома називають «релігійною версією ООН» [див.: 13].

Членство в міжрелігійних організаціях як можливість та виклик. Аналізуючи діяльність міжрелігійних організацій на прикладі Барселони й Турину, Грієра, Гіорда і Фабретті виокремлюють п’ять загальних напрямів діяльності міжрелігійних організацій: 1) міжрелігійний богословський діалог, 2) зміцнення соціальної згуртованості та медіація у розв'язанні конфліктів (сюди належить і соціальна та гуманітарна діяльність, розвиток громади (досить часто у співпраці з локальною владою)), 3) просвітництво та формування релігійної обізнаності (насамперед щодо інших традицій, що $є$ передумовою зміцнення релігійної толерантності та подолання стереотипів), 4) церемоніальна та перформативна політика (радше символічна діяльність, що слугує своєрідним прикладомдороговказом для вірних), 5) лобіювання прав та інтересів релігійних груп (захист релігійних цінностей, моніторинг дотримання гарантованих прав і привернення уваги до їх порушень, донесення власної оцінки/візії тих чи інших правових норм) [7, с. 315]. Залежно від величини та шкали діяльності організації (локальна/міжнародна) міжрелігійні організації можуть концентруватися на одному, або займатися кількома з означених напрямів.

Такий широкий спектр можливої діяльності, з одного боку, відкриває можливість для повнішої присутності у суспільному житті та на міжнародній арені, а з іншого - кидає низку викликів: робить такі організації привабливими для інструменталізації їх діяльності з політичною метою з боку окремих релігійних центрів та/або держав (наприклад див.: [6]), ставить питання щодо їх реальної репрезентативності та ефективності, що особливо актуально у випадку співпраці з нерелігійними міжнародними організаціями (як-то структури ООН, Ради Свропи) тощо. Згадані нерелігійні організації ведуть моніторинг активності акредитованих при них релігійних/міжрелігійних організацій, а у випадку номінальної участі позбавляють наданого ними статусу.

Окремий комплекс проблем становить питання розширення кола учасників міжрелігійних організацій. Якщо на шляху збільшення репрезентативності у власне міжконфесійних/міжрелігійних 
організацій можуть стояти проблеми невизнання статусу чи неприйняття/суперництво 3 певними організаціями, то міжрелігійні майданчики при нерелігійних організаціях, попри декларовану об'єктивність, часто воліють співпрацювати або 3 «непроблемними», або з транснаціональними організаціями, що значно звужує можливості «бути почутим» для національних релігійних структур. Це особливо актуально в українському випадку. Попри три десятиліття існування незалежної української держави, більшість українських релігійних організацій або представлені на міжнародній арені опосередковано через закордонні центри, або не представлені зовсім [див.: $1 ; 2 ; 3]$.

Таким чином, міжрелігійні організації $є$ самостійним об'єктом низки сучасних світових релігієзнавчих розвідок. Предметом дедалі ширших академічних дискусій стають сам зміст поняття «міжрелігійні організації» (що динамічно розширюється під впливом нових форм організації релігійної діяльності), можливі кола учасників та вплив таких організацій на суспільство загалом вибудова відносин з локальним та національними владами, нерелігійними міжнародними організаціями, вірянами різних громад. Власне, остання зі згаданих груп питань $є$ особливо актуальною в українському контексті. Більшої дослідницької уваги потребують як тема травматичного радянського досвіду релігійних контактів зі світовими міжрелігійними структурами, так і глибше дослідження сучасного життя міжрелігійних організацій: напрямів та форм їх діяльності, нових майданчиків взаємодії релігійних організації різних традицій - від університетів до нерелігійних структур різного рівня, існуючих перешкод та потенційних можливостей розширення участі українських релігійних організацій у світових міжрелігійних організаціях.

\section{ЛITEРАТУРА}

1. Бондаренко В. Особливості входження релігійних організацій України у міжнародне духовно-релігійне поле. Актуальні питання міжконфесійних взаємовідносин в Україні. К., 2006. С. 111-114.

2. Сленський В. Проблеми входження Церков і релігійних організацій України у світовий діалог конфесій, цивілізацій і культур. Релігія- 
$\overline{\text { Світ-Україна. 2011. Кн. ІІ: Міжконфесійні відносини поліконфесійної }}$ України. С. 128-138.

3. Филипович Л. Міжнародний досвід міжрелігійного діалогу. Українське релігієзнавство. 2010. № 56. С. 153-164.

4. Brodeur P. From the Margins to the Centers of Power. The Increasing Relevance of the Global Interfaith Movement. Cross Currents. 2005. № 1(55). P. 42-53.

5. Fahy J. Introduction: Interfaith on the World Stage. The Review of Faith \& International Affairs. 2018. № 3(16). P. 1-8.

6. Fletcher W. Religion and Soviet foreign policy, 1945-1970. London : Oxford University Press for the Royal Institute of International Affairs, 1973. $179 \mathrm{p}$.

7. Griera M. Initiatives interreligieuses et gouvernance locale: les cas de Barcelone et de Turin. Social Compass. 2018. № 3(65). P. 312-328.

8. Griera M. Interreligious relations and governance of religion in Europe: Introduction. Social Compass. 2018. № 3(65). P. 301-311.

9. Haynes J. Faith-Based Organizations at the United Nations. New York : Palgrave Macmillan US, 2014. 192 p.

10. Jeavons T. Identifying Characteristics of "Religious" Organizations: An Exploratory Proposal. Sacred companies: organizational aspects of religion and religious aspects of organizations. New York: Oxford University Press, 1998. P. 79-95.

11. Kunin D. A. Multifaith: New Directions. Journal of Ecumenical Studies. 2012. № 1(47). P. 101-112.

12. Lant B. Praxis community projects: A secular organization? : exploring the boundaries between religious and secular in migration support. The Refugee Crisis and Religion: Secularism, Security and Hospitality in Question. London; New York : Rowman \& Littlefield International, 2017. P. 53-59.

13. Marshall K. Global institutions of religion: Ancient movers, modern shakers. London; New York : Routledge, 2013. 223 p.

14. Martikainen T. Multilevel and Pluricentric Network Governance of Religion. Religion in the Neoliberal Age: Political Economy and Modes of Governance. Farnham : Ashgate, 2013. P. 129-142.

15. Orton A. Interfaith dialogue: Seven key questions for theory, policy and practice. Religion, State and Society. 2016. № 4(44). P. 349-365.

16. Paulsen Galal L. Routes and relations in Scandinavian interfaith forums: Governance of religious diversity by states and majority churches. Social Compass. 2018. № 3(65). P. 329-345.

17. Prideaux M. Interfaith activity and the governance of religious diversity in the United Kingdom. Social Compass. 2018. № 3(65). P. 363-377. 
18. Tracey P. Taking Religion Seriously in the Study of Organizations. Religion and organization theory. Bingley : Emerald, 2014. P. 3-21.

19. Types of International Organization. Union of International Associations. URL: https://uia.org/archive/types-organization/cc

20. Why a European network? The European Network on Religion and Belief. URL: http://enorb.eu/why-a-european-network

\section{REFERENCES}

Bondarenko, V. (2006). Features of the entry of religious organizations of Ukraine in the international spiritual and religious field. Current issues of interfaith relations in Ukraine. - Kyiv: [n.p.], 111-114. [In Ukrainian].

Yelensky, V. (2011). Problems of entry of Churches and religious organizations of Ukraine in the world dialogue of denominations, civilizations and cultures. Religion-World-Ukraine [Book II: Interfaith relations of polyfaith Ukraine]. Kyiv: [n.p.], 128-138. [In Ukrainian].

Fylypovych, L. (2010). International experience of interreligious dialogue. Ukrainian religious studies, 56, 153-164. [In Ukrainian].

Brodeur, P. (2005). From the Margins to the Centers of Power. The Increasing Relevance of the Global Interfaith Movement. Cross Currents, 55(1), 42-53.

Fahy, J. \& Haynes, J. (2018). Introduction: Interfaith on the World Stage. The Review of Faith \& International Affairs, 16(3), 1-8.

Fletcher, W. (1973). Religion and Soviet foreign policy, 1945-1970. London: Oxford University Press for the Royal Institute of International Affairs.

Griera, M., Giorda, M. \& Fabretti, V. (2018). Initiatives interreligieuses et gouvernance locale: les cas de Barcelone et de Turin. Social Compass, 65(3), 312-328. [In French].

Griera, M. \& Nagel, A.-K. (2018). Interreligious relations and governance of religion in Europe: Introduction. Social Compass, 65(3), 301-311.

Haynes, J. (2014). Faith-Based Organizations at the United Nations. New York: Palgrave Macmillan US.

Jeavons, T. (1998). Identifying Characteristics of "Religious" Organizations: An Exploratory Proposal. Sacred companies: organizational aspects of religion and religious aspects of organizations. New York: Oxford University Press, 79-95. 
Kunin, D. A. (2012). Multifaith: New Directions. Journal of Ecumenical Studies, 47(1), 101-112.

Lant, B. (2017). Praxis community projects: A secular organization?: exploring the boundaries between religious and secular in migration support. The Refugee Crisis and Religion: Secularism, Security and Hospitality in Question. London; New York: Rowman \& Littlefield International, 53-59.

Marshall, K. (2013). Global institutions of religion: Ancient movers, modern shakers. - London; New York: Routledge.

Martikainen, T. (2013). Multilevel and Pluricentric Network Governance of Religion. Religion in the Neoliberal Age: Political Economy and Modes of Governance. Farnham: Ashgate, 129-142.

Orton, A. (2016). Interfaith dialogue: Seven key questions for theory, policy and practice. Religion, State and Society, 44(4), 349-365.

Paulsen Galal, L., Lund Liebmann, L. \& Nordin, M. (2018). Routes and relations in Scandinavian interfaith forums: Governance of religious diversity by states and majority churches. Social Compass, 65(3), 329-345.

Prideaux, M. \& Dawson, A. (2018). Interfaith activity and the governance of religious diversity in the United Kingdom. Social Compass, 65(3), 363-377.

Tracey, P., Phillips, N. \& Lounsbury, M. (2014). Taking Religion Seriously in the Study of Organizations. Religion and organization theory. Bingley: Emerald, 3-21.

Union of International Associations (n.d.). Types of International Organization. Retrieved from https://uia.org/archive/types-organization/cc (Last accessed 25.09.2021)

The European Network on Religion and Belief (n.d.). Why a European network? Retrieved from http://enorb.eu/why-a-european-network (Last accessed 25.09.2021)

\section{Iuliia Korniichuk}

Candidate of Philosophical Sciences (Ph.D.), Advanced doctoral student at the Department of Theology and Religious Studies, National Pedagogical Dragomanov University; Kyiv, Ukraine; e-mail: iu.korniichuk@npu.edu.ua; ORCID: https://orcid.org/0000-0003-3346-4920 


\title{
Interreligious organizations: State and directions of studies in Ukrainian context
}

\begin{abstract}
In contrast to interreligious dialogue, which has been the subject of careful scrutiny by both Ukrainian and foreign researchers of religion, attention to interreligious organizations remains disproportionately lower than their role in public life and in the international arena. This article aims to present a systematic review of the main directions of current researches on interreligious organizations. It consistently covers four aspects: 1) the possible reasons for the previous low research attention to interfaith organizations (in particular, the impact of the secularization theory and the relative "youth" of the majority of interfaith organizations); 2) the problem of interpretation the term "interreligious organizations" (e.g., expansion of the range of actors who can act on behalf of religious organizations; correlation of approaches to interreligious organizations in religious studies with the UN criteria for defining international organizations); 3) current approaches to the classification of interreligious organizations based on the pool of participants and difficulties of adapting these classifications to the Ukrainian context - untranslatabilities, changes of emphasis, national preferences and connotations; 4) functions of interfaith organizations on international arena and its challenges: threats of political instrumentalization of religion, problem of representativeness and inclusion of all actors, which is especially relevant for Ukrainian religious organizations, most of which do not have independent representation in international interfaith organizations. The conclusions outline the prospects for further study of the topic in the context of growing diversity of interreligious organizations and of the entry of Ukrainian religious organizations in the international religious field.
\end{abstract}

Keywords: interreligious organizations, interfaith organizations, religion in public sphere, religion and organization theory, international engagement of religious organizations, faith-based organizations, Parliament of the World's Religions, World Council of Churches. 